\title{
Academic Achievement and Failure in University Studies: Motivational and Emotional Factors
}

\author{
Raquel Gilar-Corbi ${ }^{1, * \mathbb{C}}$, Teresa Pozo-Rico ${ }^{1}{ }^{\mathbb{D}}$, Juan-Luis Castejón ${ }^{1}{ }^{(0)}$, Tarquino Sánchez ${ }^{2} \mathbb{D}$, \\ Ivan Sandoval-Palis ${ }^{3}$ (i) and Jack Vidal ${ }^{1}$ (D) \\ 1 Department of Developmental Psychology and Didactics, University of Alicante, 03080 Alicante, Spain; \\ teresa.pozo@ua.es (T.P.-R.); jl.castejon@ua.es (J.-L.C.); jivc1@alu.ua.es (J.V.) \\ 2 Department of Electronics, Telecommunications and Information Networks, Escuela Politécnica Nacional, \\ Quito 17-01-2759, Ecuador; tarquino.sanchez@epn.edu.ec \\ 3 Basic Training Department, Escuela Politécnica Nacional, Quito 17-01-2759, Ecuador; \\ ivan.sandoval@epn.edu.ec \\ * Correspondence: raquel.gilar@ua.es
}

Received: 8 November 2020; Accepted: 23 November 2020; Published: 24 November 2020

\begin{abstract}
Universities are committed to offering quality education; however, a high rate of academic failure is often observed in the first year of studies. Considering the impact that motivation and emotional aspects can have on students' commitment to study and therefore on their academic performance, achievement, and well-being, this study aims to identify the factors associated with academic success or failure in 1071 students entering the National Polytechnic School (Quito, Ecuador). The data were compiled from the existing computer records of the university with the permission of the responsible administrative staff. A predictive model has been used and a binary logistic regression analysis was carried out through the step-forward regression procedure based on the Wald statistic to analyze the predictive capacity of the variables related to emotional intelligence, motivational and self- regulated socio-cognitive skills, goal orientation, and prior academic achievement (measured by university entrance marks and through a knowledge test carried out at the beginning of the university academic year). To determine the cut-off point for the best discriminatory power of each of the variables, a Receiver Operating Characteristics (ROC) curve analysis has been used. The results indicate that the variables that are significant in the prediction of academic success or failure are the two academic performance measures: the emotional attention variable, and the performance-approach goals and the motivational self-efficacy variable. Additionally, the highest predictive power is displayed by the prior academic performance measure obtained through the knowledge test conducted at the beginning of the university course.
\end{abstract}

Keywords: academic motivation; self-efficacy; academic failure; emotional intelligence; academic achievement; higher education

\section{Introduction}

Universities are committed to providing quality education and therefore it is imperative to constantly analyze if there are any existing problems to ensure that action can be taken to address these [1]. This evaluation highlights various research questions, student failure manifested especially during the first year of studies being one of the most significant [2]. According to existing data, in the last decade, approximately $50 \%$ of students failed in the first year of university studies in South America [3]. According to Canales and De los Ríos [4], the transition or adaptation to the university is a stressful process as students have to deal with a complex cognitive environment that they have 
not been exposed to in previous educational stages. Additionally, a lack of proper study habits and inability to handle content can have an adverse impact on academic performance.

Higher education institutions in Latin-America have the objective of contributing to social development [5]; therefore, they have great interest in improving the training offered to students as well as improving success rates. On the one hand, it is possible that there are good students who might present disadvantages that would make their success in higher education institutions difficult (social disadvantage, emotional disadvantage, emotional disadvantage, etc. .. ). Nevertheless, these students could be excellent professionals in the labor world. To that end, if higher education institutions offer a concrete reinforcement by providing students with the resources and strategies necessary to successfully complete their training, this would avoid a loss of talent and a loss of possible good professionals from the world of work. On the other hand, there are economic concerns. Given that governments invest a lot of resources in public and community colleges and on student grants, high dropout rates mean that a lot of these invested resources have been lost.

Several studies have indicated that academic failure is influenced by an interaction of several decisive factors throughout the academic process [6-8]. Lack of prior academic preparation and economic and financial difficulties have been identified as potential causes of failure in the higher education system $[9,10]$. However, these variables are not the only predictors of academic failure, as failure should be considered a collective phenomenon in which endogenous and exogenous factors converge [11]. According to Díaz-Morales and Escribano [12], academic achievement is the product of a set of psychological, social, and economic factors that lead to the proper development of students.

Several studies have been conducted in the last two decades that have analyzed the variables associated with academic success or failure in higher education. According to a systematic review by Schneider and Preckel [13], the variables that explain academic achievement are related to instructional factors such as social interaction, evaluation and feedback, clear information, extracurricular training programs, and so on, and also variables related to the student, such as intelligence, previous academic performance, motivation, strategies, and so on. This study primarily focuses on the variables related to the student in an attempt to explain the phenomenon of academic success or failure in higher education.

\subsection{Motivational and Self-Regulated Socio-Cognitive Skills}

Several studies have identified that motivation and self-regulated learning are key skills for higher education. These involve the mode and grade in which the subject actively participates at the cognitive, motivational, and behavioral level in the learning process [14,15].

Accurate learning strategies that aid student autonomy and adequate feedback for students to regulate their training have a positive impact on academic progress [16,17]. Arriaga, Burillo, Carpeño, and Casaravilla [18], state that students who are committed to study tasks and perceive that the support by the teaching staff is based on their requirements, usually have better academic results.

Additionally, low motivation has been associated with academic failure [19-21]. In fact, it has been observed that low motivation and lack of self-regulated socio-cognitive skills have a direct relationship with dropout intention and also on academic motivation, and the fit between students' self-construal and university norms has been positively associated with well-being, healthy student life, and academic achievement [22].

\subsection{Students' Goal Orientations}

Goal orientation is important to improve the learning process for students and to support their ability to lead the learning process and to ensure that they engage in achievement oriented behavior [23]. Goal orientation has been associated with enriching the academic environment, enhancing motivation, and supporting student achievement [24,25].

Studies have elaborated on the positive impact of student's achievement goals on interest in an academic discipline, motivation, learning, positive grades, achievement, and long-term academic performance $[26,27]$. 
Additionally, the perception of students regarding the goal structure has been associated with a positive relationship in the academic context, emotional support perception, academic self-concept, achievement of academic goals, intrinsic motivation, and student perception regarding belongingness in the academic institution [28-30].

\subsection{Emotional Competences}

Studies, in the last decade, have focused on the importance of the development of emotional competences for students' academic and professional success and for the prevention of academic failure in higher education [31].

Scientific literature indicates the need to include training for this competence in the intervention programs that are intended to stop university abandonment and to ensure that the students perform well academically [32-35].

Additionally, a relationship has been reported between positive emotions associated with learning and a decrease in disengagement or withdrawal, specifically in the case of students who face difficulties in the first year of university [36].

Prior research has established that emotional competence is associated with positive cognitive and behavioral beliefs and responses that have an impact on academic achievement and is considered an important aspect of individual success [37-39].

Negative emotions such as fear of failure have been transculturally associated with underachievement, defensive pessimism, and academic disengagement. Conversely, it has been established that positive emotions are key for academic success orientation, and these indicate a low perception of helplessness and self-handicapping [40].

Arriaga et al [18] found that students who are exposed to a greater group experiences tend to have higher commitment and achieve better results. Therefore, there is a greater probability that they would continue studying.

Furthermore, Tinto [41] highlights the influence of the relationships established by students (both with other students and with faculty staff) on the number of students who drop out and points out the need to apply cooperative pedagogies and education services, such as complementary support for class activities, to prevent the same.

The learning environment can be optimized by ensuring a positive emotional climate, and this is aligned with development opportunities for higher education. Therefore, institutes that offer higher education can play an important role in ensuring quality-related educational development [38].

\subsection{Previous Academic Records}

Montmarquette, Mahseredjian, and Houle [42] state that variables related to performance in the previous academic stages and within the university system are correlated with academic success and the permanence of the student in the degree.

Previous studies have elaborated on the importance of reducing the rate of dropouts and alleviating academic failure by taking into consideration the analyses of previous academic records [43]. Based on this, it is possible to provide students with the necessary resources and methods to ensure continuity in education and observe their pattern of behavior, the changes during the course, and the impact on academic development.

Researchers have suggested this strategy based on the evidence presented by objectively analyzing previous records of students to identify at-risk students and initiate enriched pedagogical action that would prevent major academic difficulties and encourage the development of vulnerable students [44].

Previous research has established a predictive model based on students' previous grades, to identify those who may face more difficulties in the first year of university studies [45,46]. Identification of these students and the common factors that lead to university dropouts has been a challenge for institutes offering higher education. For this purpose, previous academic records of students provide information that can be used to design timely intervention programs based on the student's learning 
profile. Previous academic records facilitate the early prediction of underachieving students and can be used as a warning sign to ensure timely intervention.

According to some studies [47], previous academic records have been positively associated with mastery and performance-approach goals and have been negatively associated with performance-avoidance goals and academic anxiety.

This implies that a student's previous academic records could be analyzed to garner information and create support programs.

To conclude, it can be stated that to prevent the high dropout rate of university students, especially those with psychosocial needs and increased social vulnerability, educational intervention is required [48-53]. This study analyses the above mentioned variables to establish how they affect academic success or failure in order to promote effective prevention measures, create new support opportunities, and reduce the university dropout rate, especially during the first year of university.

Several studies have been conducted to identify the factors that have an impact on student failure [54]. Admission to higher education institutions in Ecuador is regulated by the admission process wherein students have to clear the National Exam of Educational Evaluation [55], and a seat is secured in the university based on results of the exam. This exam includes assessments based on the linguistic, mathematical, abstract aptitude, social, and scientific knowledge and abilities of the students. To secure their admission at the university, students have to clear a 'levelling course', which is a beginner course that includes classes for basic subjects. However, due to the high failure rate of students on this course (about $68 \%$ of students fail), the effectiveness of the qualification of this program has been raised for the selection of students. Consequently, a broader analysis should be conducted to identify the factors associated with university academic success or failure.

These factors and their influence on students' academic performance are important and should be analyzed to identify students who are at risk of academic failure at an early stage to implement the requisite actions for improvement in the educational process [56].

This study aims to identify the factors associated with the success or failure of the students on the levelling course offered by the National Polytechnic School of Equador (EPN). Four key variables have been analyzed. These are as follows: (1) motivational and self-regulated socio-cognitive skills; (2) students' goal orientations; (3) emotional competences (EI); and (4) previous academic performance.

The objective of this study is to predict the probability of the success or failure of the students based on the scores of the EPN levelling course.

The hypotheses of the study are as following:

1. Students who present higher scores in previous academic performance will present a lower probability of academic failure [42];

2. Students with higher emotional intelligence scores will have a higher probability of academic success [37-39];

3. Students who have higher scores in achievement goals will have a greater probability of academic success [26,27];

4. Students who have higher scores in motivational and self-regulated socio-cognitive skills will have a greater probability of academic success [19-21].

\section{Materials and Methods}

\subsection{Participants}

The participants for this study were 1013 students enrolled in the EPN levelling course. This course has one semester and is compulsory for all students at EPN. It is a beginner's course in which the subjects that are considered as basic subjects are taught and students have to clear the course to continue with university studies. The subjects included are the fundamentals of mathematics, physics, geometry and trigonometry; the fundamentals of chemistry; and language and communication. In terms of gender, $72.2 \%$ of the students enrolled for this course were male, while the rest were female. 
In terms of ethnicity, $93.5 \%$ of the students declared that they were mestizo, the rest declared that they were Afro-American, Black, Indigenous, Montubio, Mulatto, or White, while $0.2 \%$ declared that they belonged to other ethnic groups. Out of the total students who enrolled in the remedial course, $17.27 \%$ passed, while $82.73 \%$ failed.

\subsection{Instruments}

\subsubsection{Prior Academic Performance}

Two averages have been used to evaluate this variable. These are: (a) Postulation grade (access grade to the university studies); this is the grade obtained by the student in the university access exam. The student is graded out of a total of 1000 marks, where a higher score implies a better performance. (b) Diagnostic test score; this is based on a test conducted at the beginning of the university course. The test consists of 80 items (55 items in mathematics skills and 25 items in language and communication skills) (Please see Supplementary File for more information about Diagnostic test).

\subsubsection{Goal Orientation}

The Academic Goals Questionnaire by Skaalvik [57] has been used to evaluate learning and achievement approach goals. This instrument assesses four subscales: (1) learning goals (or approach task), (2) performance-approach goals (or self-improvement), (3) performance avoidance goals (or self-defence), and (4) achievement avoidance goals associated with academic work. It includes 22 Likert-type items, with five response options. This instrument has been used in a number of studies regarding university students [58-60] and has been proven to be a reliable and valid scale for the evaluation of academic goals. According to Valle et al. [61], the reliability index for this is between Cronbach's alpha 0.85 (learning goals) and 0.89 (performance-approach goals).

\subsubsection{Motivational and Self-Regulated Socio-Cognitive Skills}

The Motivated Strategies Learning Questionnaire (MSLQ) has been used [62] to assess this factor. The abbreviated questionnaire contains 44 items that are answered with a Likert-type scale wherein the range is between 1 and 7 . The questionnaire is divided into two parts; that is, motivation and self-regulated learning strategies. These, in turn, are divided into subscales. The motivation section is divided into self-efficacy (which implies how competent students feel about their performance), intrinsic motivation (which implies the level of personal commitment that students have towards academic obligations, beyond complying with the assessments during the school period), and anxiety before evaluations (this includes the anxiety level that students experience when faced with academic evaluation situations). The self-regulated learning strategies are divided into the use of metacognitive strategies (this includes the level of resource management and metacognitive strategies used for academic processes) and self-regulation (this includes the level of autonomy and self-discipline that students possess to carry out the academic processes). Pintrich and De Groot [62] reported reliability indices for motivation as $\alpha=0.75$ (anxiety before evaluations) and $\alpha=0.89$ (self-efficacy), and for self-regulated learning strategies as $\alpha=0.74$ (self-regulation) and $\alpha=0.83$ (use of cognitive strategies). A review conducted by Mayer, Faber, and Xu [63] indicates that the MSLQ is the most widely used instrument to assess motivation in educational contexts. Therefore, it has become a standard instrument in research in the field of motivation and self-regulation [64].

\subsubsection{Emotional Intelligence}

The Trait Meta-Mood Scale (TMMS) based on Salovey and Mayer's model of EI is a self-analysis measure and consists of three dimensions with adequate psychometric indices [65]. These are emotional attention, clarity of feelings, and mood repairs. In the study conducted by them, it has been used for the validation of a Spanish data sample and has indicated psychometric properties similar to those of 
the original scale, implying that the reliability for each component is as follows: attention $\alpha=0.90$, clarity $\alpha=0.90$, and repair $\alpha=0.86$ [66].

\subsubsection{Academic Success/Failure}

This involves assessing if a student has cleared the academic levelling course or not.

\subsection{Procedure}

Data from 1013 first-year students enrolled in EPN, corresponding to the entire cohort that entered the university in 2018B (second semester) was analyzed. EPN is an engineering university that receives approximately $2 \%$ of the total student of all universities in Ecuador. Data were collected from the existing computer records with prior permission from the academic staff at the institution. The data were anonymous.

\subsection{Data Analysis}

A predictive model was used and a binary logistic regression analysis was conducted through the forward stepwise regression procedure based on the Wald statistic to analyze the predictive capacity of the variables related to prior academic performance, emotional intelligence, motivation, and academic goals on the academic success or failure of students. This model allowed estimation of the probability that an event could happen (in our case, academic failure), as opposed to not happening, in the presence of one or more predictors. Additionally, the weightage of each of the independent variables on the probability of academic success or failure was analyzed.

An analysis using Reciver Operating Characteristics (ROC) curve was conducted to determine the cut-off point with the best discriminative power of each of the variables studied for academic success or failure.

All analyses were conducted with the SPSS 20 computer program.

\section{Results}

\subsection{Logistic Regression Analysis}

The independent variables (covariates) for the analysis were previous performance scores (diagnostic test score and university access score), emotional intelligence (emotional attention, clarity of feelings, and mood repairs), academic goals (learning goals, performance-approach goals, performance avoidance goals, and achievement avoidance goals associated with academic work), and motivation (self-efficacy, intrinsic motivation, anxiety before evaluations, use of metacognitive strategies, and self-regulation). The dependent variable included the dichotomous variable pass or fail.

Therefore, a predictive model of academic success or failure was established.

The Hosmer and Lemeshow test to evaluate the goodness of fit of the model yielded satisfactory values; therefore, it can be concluded that the model fits the data well.

Table 1 shows the variables that have been significant in the model to predict academic success or failure.

The Nagelkerke $\mathrm{R}^{2}$ statistic estimated a model fit value of 0.46 , and the model correctly estimated $88.4 \%$ of the cases. The odd ratio levels were higher than 1 for the attention and performance goals variables, indicating that the probability of academic failure increases 1.22 times for each point that the attention score increases and 1.38 times for each point that the performance goals score increases. The odd ratio levels were lower than 1 for the variables, diagnostic test score, university access score, and motivation-self-efficacy, indicating that the probability of academic failure decreases 5.29 times for each point that the score in the diagnostic test increases, 1.47 times for each point that the university access score increases, and 1.47 times for each point that the motivation-self-efficacy variable increases. 
Table 1. Significant variables in the logistic regression model.

\begin{tabular}{ccccccccc}
\hline & & & & & & & \multicolumn{2}{c}{$\begin{array}{c}\text { 95\% Confidence } \\
\text { Interval O.R. }\end{array}$} \\
\cline { 3 - 8 } & B & s.e. & Wald & df & Sig. & Exp(B) & Lower & Upper \\
\hline Diagnostic test score & -1.663 & 0.140 & 141.853 & 1 & 0.000 & 0.189 & 0.144 & 0.249 \\
University access score & -0.387 & 0.129 & 8.932 & 1 & 0.003 & 0.679 & 0.527 & 0.875 \\
Emotional attention & 0.203 & 0.103 & 3.904 & 1 & 0.048 & 1.225 & 1.002 & 1.498 \\
Performance-approach goals & 0.329 & 0.118 & 7.697 & 1 & 0.006 & 1.389 & 1.101 & 1.752 \\
Self-efficacy & -0.392 & 0.123 & 10.147 & 1 & 0.001 & 0.676 & 0.531 & 0.860 \\
Constant & 2.533 & 0.157 & 261.402 & 1 & 0.000 & 12.592 & & \\
\hline
\end{tabular}

Note. $\mathrm{B}=$ coefficient; s.e.= standard error; Wald= Wasld statistic; $\mathrm{df}=$ degree of freedom; Sig.= significance; O.R. = odd ratio.

\subsection{ROC Curve Analysis}

This analysis summarizes the predictive capacity of a logistic regression model through the concept of sensitivity (predicting success when it is true) and through the concept of specificity (predicting failure when it is true). In this study, academic failure or success is defined as the state variable, and the five variables identified as significant by logistic analysis are defined as contrast variables.

To represent the discriminative capacity of each of the contrast variables, the area under the ROC curve (AUC) parameter was estimated. The graph of the ROC curve illustrates the ratio of true positives (sensitivity, Y-axis) versus the ratio of false positives (X-axis). Therefore, the variable will have better discriminative power the higher the true positives and the lower the false positives.

Table 2 shows the AUC values for each of the variables identified as significant in the logistic analysis.

Table 2. Area under the curve.

\begin{tabular}{cccccc}
\hline Contrast Result Variables & \multirow{2}{*}{ Area } & \multirow{2}{*}{ S.E. } & Sig. & \multicolumn{2}{c}{ 95\% Confidence Interval } \\
\cline { 5 - 6 } & & & & Lower Limit & Upper Limit \\
\hline Diagnostic test score & 0.986 & 0.003 & 0.000 & 0.980 & 0.992 \\
University access score & 0.826 & 0.019 & 0.000 & 0.790 & 0.863 \\
Self-efficacy & 0.600 & 0.027 & 0.000 & 0.548 & 0.652 \\
Emotional attention & 0.538 & 0.028 & 0.174 & 0.484 & 0.593 \\
Performance-approach goals & 0.557 & 0.028 & 0.043 & 0.503 & 0.611 \\
\hline
\end{tabular}

The two variables with the best predictive values include those associated with previous academic performance, which are diagnostic test score, with an AUC $=0.986$ (CI: 0.980-0.992), and university access score, with an AUC $=0.826$ (CI: 0.790-0.863). The diagnostic test score has the greatest discriminatory power. Figure 1 shows the graphical representation of the AUC for each of the variables analyzed.

To determine the cut-off point at which the highest sensitivity and specificity are reached, the Youden test (sensitivity + specificity-1) was used. This stipulates the cut-off point with the highest sensitivity and specificity together.

Therefore, for the diagnostic test score, the value of 1.13 had the highest discriminative power to detect academic failure with a sensitivity of $95 \%$ and specificity of $50 \%$. For the university access score, the value of 0.527 had the highest discriminative power to detect academic failure with a sensitivity of $85 \%$ and specificity of $72 \%$. For self-efficacy, the value of -0.69 had the highest discriminative power to detect academic failure with a sensitivity of $90 \%$ and specificity of $25 \%$. For emotional attention, the value of -0.06 had the highest discriminative power to detect academic failure with a sensitivity of $54 \%$ and specificity of $53 \%$. For performance-approach goals, the value of -0.80 had the highest discriminative power to detect academic failure with a sensitivity of $80 \%$ and specificity of $30 \%$. 


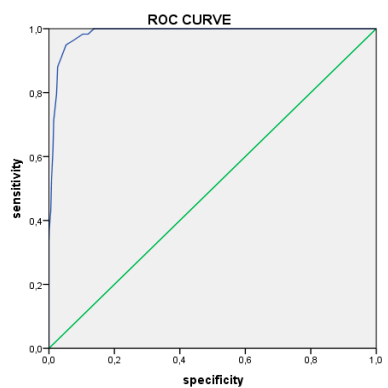

(a) Diagnostic test score

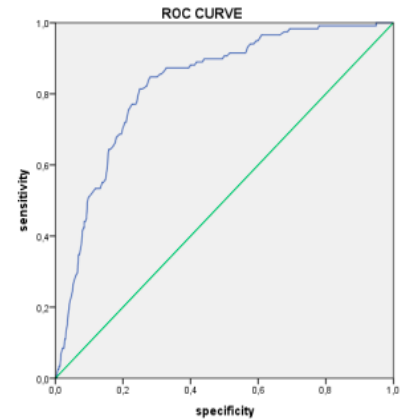

(b) University access score

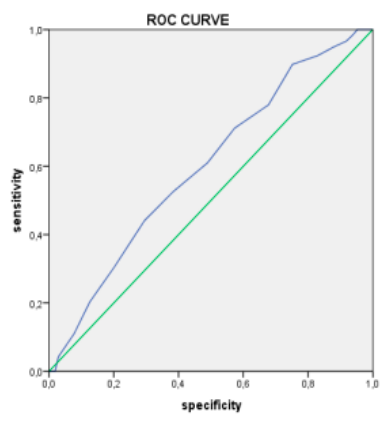

(c) Self-efficacy

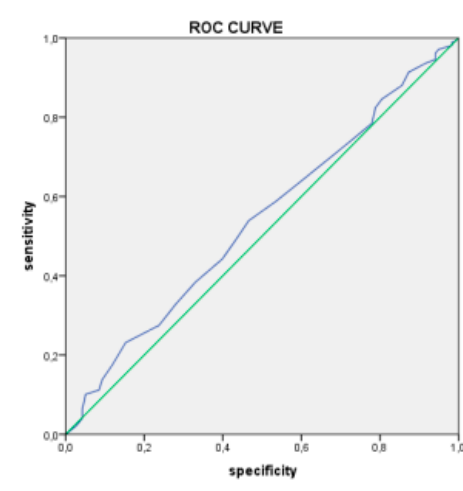

(d) Emotional attention

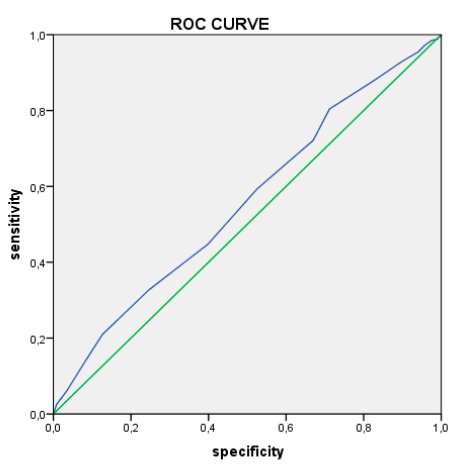

(e) Performance-approach goals

Figure 1. Area Under the Curve (AUC) representation.

\section{Discussion}

Considering the impact that motivation and emotional aspects can have on a student's commitment to studying and therefore on academic performance, achievement, and well-being, this study attempts to identify the factors associated with academic success or failure in students entering EPN.

The results indicate that academic success or failure can be predicted by variables associated with prior academic performance and motivational and emotional aspects. Specifically, the results indicated that students who are susceptible to academic failure have a lower score in the diagnostic test, university access test, and motivational variable self-efficacy test. Similarly, these students have higher scores in the variables of emotional attention and performance-approach goals. Additionally, several studies have shown that offering the necessary institutional support to students is a key aspect that will allow them to face emotional and personal issues, achieve positive self-esteem, and deal with any sense of failure within them. With this support, the university will promote academic performance and avoid the failure in university studies [67-69].

The first hypothesis of the study, students who have higher scores in previous academic performance will have a lower probability of academic failure, has been confirmed. Previous performance has been proven as being the most predictive indicator of academic success or failure. Numerous existing studies also confirm these results. Lin, Yu, and Chen [70] found that the Grade Point Average (GPA) obtained secondary education is one of the predictive factors of academic success for first-year students. They also proposed some interesting interventions to reverse the chances of academic failure, including remedial English courses, on-campus jobs, and on-campus residency, as they found that these interventions have a positive impact on retention.

In another study, Flores and Lever [71] found that the students who had better results in the field of science also had better grades in secondary studies. Castrillón [72] found significant correlations between current performance and the grade obtained in secondary education. Rojas-Torres [73] found 
that the best predictors of performance in college were the grades obtained in secondary education and in the university entrance exam. Rodrigo et al. [74] confirmed that academic failure is related to a lower score in the university entrance exam and includes a variable that is largely associated with this failure: students' dedication to part-time studies.

In most of the studies, previous performance has been measured using college entrance grades and/or grades in high school studies. This study includes the university entrance qualification variable and also includes another measure of previous performance that has not been used in the existing literature (but which we consider to be highly explanatory), perhaps due to the difficulty associated with obtaining it. This factor is the previous performance measured at the beginning of university through a test carried out before starting university studies that assesses the knowledge level of the students (related to the specific knowledge that is considered key for the studies to be pursued) with which the student accesses the institution of higher education, in this case, to a higher polytechnic school. This variable indicates a greater predictive power regarding academic success/failure. Therefore, this study proposes the performance of these diagnostic tests at the beginning of university studies to identify the students with a higher risk of failure and thereby proposes educational measures, such as reinforcement courses, to address this, in line with the proposal by Lin, Yu, and Chen [70].

The second hypothesis of this study, students with higher emotional intelligence scores have a higher probability of academic success, has been partially confirmed. The only variable related to emotional intelligence that was significant in predicting academic failure is emotional attention. The students who suffered academic failure had the highest scores in emotional attention. A score that is too high in emotional attention can be detrimental as it implies excessive attention to emotions and can even indicate a blockage or difficulty in correctly perceiving the rest of the stimuli, which could impair academic performance. As previously stated, emotional competence has an impact on academic performance [37-39]. Negative emotions are associated with underachievement [40], and excessive emotional attention can affect academic performance, as has been proven by the data analyzed. For this reason, it is necessary that university institutions and educational reforms include the development of emotional competencies, because the improvement of these competencies has proven necessary for the development of students. Emotional competencies will help university students meet challenges, promote entrepreneurship, and achieve academic and career success [75-80]. As a practical implication of these findings, it is proposed that education and training associated with the emotional aspects for university students is included in the first few courses to enhance and develop these attributes in students to avoid academic failure [32-35].

The third hypothesis of the study, students who have higher scores in achievement goals have a greater probability of academic success, has not been confirmed by the study. Data reveals that students with higher scores in performance-approach goals are more likely to face academic failure. Regarding the relationship between academic goals and performance, some authors $[81,82]$ consider that these two variables change as students progress through the educational system. Therefore, learning or mastery of goals will be more beneficial in primary courses showing a positive relationship with academic performance [83], while they would lose importance at the secondary and university level, where the relationships would be weaker [61].

The fourth hypothesis of the study, students who have higher scores in motivational and self-regulated socio-cognitive skills will have a greater probability of academic success, is established. The results indicate that students who obtain lower scores in self-efficacy are more likely to suffer academic failure.

Promoting a strong sense of self-efficacy in the higher education context is an important factor to improve academic success among university students and for successful completion of studies [84]. This study encourage the use of self-efficacy experience among university students (especially in students with the highest gaps) to ensure better academic performance $[85,86]$. 
Additionally, research has indicated that it is important to develop student's self-efficacy in higher educational programs to develop the required knowledge, skills, and competencies as student's self-efficacy plays a predicting and mediating role in achievements, motivation, and learning [87].

Several studies have indicated that to determine the stay at the university and academic success, development of academic support programs where self-efficacy is disclosed as a key factor to ensure motivation and articulate self-regulated socio-cognitive behavior, is imperative [88-90].

According to Frawley, Ober, Olcay, and Smith [91], self-efficacy should be a key consideration in programs that aim to support students facing difficulties in higher education and would be useful in advancing existing program investment and support in this sector. Evidence suggests that there is a need to further offer assistance to prevent the high academic failure in students with more difficulties, especially at the beginning of university education. This initial period is critical because, in it, students are faced with new situations and contexts that will challenge their skills and resources [44-46].

As our results shown, given the impact of previous academic performance $[70,92]$ and socio-emotional [32-35] and motivational aspects [88-90] on academic success or failure, it would be important to implement actions that enhance these to reduce the chances of academic failure. Therefore, improving the quality of teaching offered in higher education institutions, and making them more equitable and sustainable, is imperative to try to provide students with the resources and strategies necessary to successfully complete their training, and also to ensure that potential good professionals are not lost.

We can point out some limitations of the present study that lead us to propose future works. In the first place, this research has been carried out including only students from one institution, the National Polytechnic School (EPN receives approximately $2 \%$ of the total number of students admitted from all universities in Ecuador). It is also a polytechnic institution related to science, technology, engineering and mathematics (STEM) education. Therefore, it would be necessary to extend these studies to other university institutions and different areas of knowledge. Secondly, it would be interesting to carry out these types of studies by also including other variables, such as sociodemographic variables, in order to be able to make a more complete explanation of academic success/failure in higher education.

Supplementary Materials: The following are available online at http://www.mdpi.com/2071-1050/12/23/9798/s1, the datasets generated for this study are available on request to the corresponding author. Supplementary File: Diagnostic test.

Author Contributions: Conceptualization, I.S.-P., J.V., T.P.-R., and R.G.-C.; methodology, J.-L.C.; software, R.G.-C.; validation, T.S., T.P.-R., and R.G.-C.; formal analysis, J.-L.C. and R.G.-C.; data curation, R.G.-C.; writing-original draft preparation, R.G.-C., T.P.-R., J.-L.C., T.S., J.V., and I.S.-P.; writing-review and editing, R.G.-C. and J.-L.C.; project administration, T.S. All authors have read and agreed to the published version of the manuscript.

Funding: This research was supported by National Secretariat of Higher Education, Science and Technology, SENESCYT (PIC-18-INE-EPN-002).

Conflicts of Interest: The authors declare no conflict of interest. The funders had no role in the design of the study; in the collection, analyses, or interpretation of data; in the writing of the manuscript, or in the decision to publish the results.

\section{References}

1. Sandoval, I.; Sánchez, T.; Naranjo, D.; Jiménez, A. Proposal of a mathematics pilot program for engineering students from vulnerable groups of Escuela Politécnica Nacional. In Proceedings of the LACCEI International Multi-Conference for Engineering, Education and Technology, Montego Bay, Jamaica, 24-26 July 2019. [CrossRef]

2. Baars, G.J.; Stijnen, T.; Splinter, T.A. A model to predict student failure in the first year of the undergraduate medical curriculum. Health Prof. Educ. 2017, 3, 5-14. [CrossRef]

3. Parrino, C. Deserción en el Primer año Universitario. Dificultades y Logros. X Coloquio Internacional Sobre Gestión Universitaria en América del Sur 2010. Available online: https://core.ac.uk/download/pdf/30377642. pdf (accessed on 23 November 2020).

4. Canales, A.; De los Ríos, D. Retención de estudiantes vulnerables en la educación universitaria. Calid. Educ. 2009, 50-83. [CrossRef] 
5. Arocena, R.; Sutz, J. Latin American Universities: From an original revolution to an uncertain transition. High. Educ. 2005, 50, 573-592. [CrossRef]

6. Heredia, D.; Amaya, Y.; Barrientos, E. Student dropout predictive model using data mining techniques. IEEE Lat. Am. Trans. 2015, 13, 3127-3134. [CrossRef]

7. Amo, C.; Santelices, M.V. Trayectorias Universitarias: Más que Persistencia o Deserción. Congresos CLABES. 2017. Available online: https://revistas.utp.ac.pa/index.php/clabes/article/view/1676/2412 (accessed on 23 November 2020).

8. Orozco Lara, H.; Suarez Silva, J.; Olarte Galeano, M.; Cabanzo Carreño, C.; Beltran Ariza, A. Estudio Factores Asociados a la Deserción Estudiantil en la Universidad Minuto de Dios de la Sede Virtual ya Distancia. Congresos CLABES. 2017. Available online: https://revistas.utp.ac.pa/index.php/clabes/article/view/1691/ 2427 (accessed on 23 November 2020).

9. Amo, C.; Santelices, M.V. Trayectorias universitarias: Más que persistencia o deserción en los estudios universitarios. In Proceedings of the VII CLABES Séptima Conferencia Latinoamericana sobre el Abandono en la Educación Superior, Córdoba, Argenitna, 15-17 November 2017.

10. Montoya Gutiérerz, G. Estudio factores asociados al abandono temprano de la educación superior. In Proceedings of the IV CLABES Cuarta Conferencia Latinoamericana sobre el abandono en la Educación Superior, Medellín, Colombia, 22-24 October 2014. [CrossRef]

11. Vásquez-Martínez, C.R.; Rodríguez-Pérez, M.C. La deserción estudiantil en educación superior a distancia: Perspectiva teórica y factores de incidencia. Revista Latinoamericana de Estudios Educativos (México). Available online: https://www.redalyc.org/articulo.oa?id=27011410005 (accessed on 23 November 2020).

12. Díaz-Morales, J.F.; Escribano, C. Social jetlag, academic achievement and cognitive performance: Understanding gender/sex differences. Chronobiol. Int. 2015, 32, 822-831. [CrossRef]

13. Schneider, M.; Preckel, F. Variables associated with achievement in higher education: A systematic review of meta-analyses. Psychol. Bull. 2017, 143, 565-600. [CrossRef]

14. Lopez, B.G.; Perez-Perez, C.; Garcia-Garcia, F.J.; Beut, J.A.G.; Poblador, N.P. The Skill of Learning to Learn at University. Proposal for a Theoretical Model. Educacion XX1 2020, 23, 19-44. [CrossRef]

15. Zimmerman, B.J. Becoming a self-regulated learner-Which are the key subprocesses. Contemp. Educ. Psychol. 1986, 11, 307-313. [CrossRef]

16. Van Horne, S.; Curran, M.; Smith, A.; VanBuren, J.; Zahrieh, D.; Larsen, R.; Miller, R. Facilitating Student Success in Introductory Chemistry with Feedback in an Online Platform. Technol. Knowl. Learn. 2018, 23, 21-40. [CrossRef]

17. Roberts, L.D.; Howell, J.A.; Seaman, K. Give Me a Customizable Dashboard: Personalized Learning Analytics Dashboards in Higher Education. Technol. Knowl. Learn. 2017, 22, 317-333. [CrossRef]

18. Arriaga, J.; Burillo, V.; Carpeño, A.; Casaravilla, A. Caracterización de los tipos de abandono. Dividamos el problema y venceremos más fácilmente. In Proceedings of the Congresos CLABES, Managua, Nicaragua, 17-18 November 2011.

19. Anderman, E.M.; Maehr, M.L. Motivation and schooling in the middle grades. Rev. Educ. Res. 1994, 64, 287-309. [CrossRef]

20. Gangolu, K.R. Academic Motivation and Adjustment as Predictors of Academic Achievement Among Adolescents. J. Psychosoc. Res. 2019, 14, 393-402. [CrossRef]

21. González, A.; Donolo, D.; Rinaudo, C.; Paoloni, V. Relaciones entre motivación, emoción y rendimiento académico en universitarios. Estud. Psicol. 2011, 32, 257-270.

22. Suhlmann, M.; Sassenberg, K.; Nagengast, B.; Trautwein, U. Belonging mediates effects of student-university fit on well-being, motivation, and dropout intention. Soc. Psychol. 2018, 49, 16-28. [CrossRef]

23. Patrick, H.; Kaplan, A.; Ryan, A.M. Positive Classroom Motivational Environments: Convergence between Mastery Goal Structure and Classroom Social Climate. J. Educ. Psychol. 2011, 103, 367-382. [CrossRef]

24. Meece, J.L.; Anderman, E.M.; Anderman, L.H. Classroom goal structure, student motivation, and academic achievement. Annu. Rev. Psychol. 2006, 57, 487-503. [CrossRef]

25. Senko, C.; Hulleman, C.S.; Harackiewicz, J.M. Achievement Goal Theory at the Crossroads: Old Controversies, Current Challenges, and New Directions. Educ. Psychol. 2011, 46, 26-47. [CrossRef]

26. Harackiewicz, J.M.; Barron, K.E.; Pintrich, P.R.; Elliot, A.J.; Thrash, T.M. Revision of achievement goal theory: Necessary and illuminating. J. Educ. Psychol. 2002, 94, 638-645. [CrossRef] 
27. Harackiewicz, J.M.; Barron, K.E.; Tauer, J.M.; Carter, S.M.; Elliot, A.J. Short-term and long-term consequences of achievement goals: Predicting interest and performance over time. J. Educ. Psychol. 2000, 92,316-330. [CrossRef]

28. Polychroni, F.; Hatzichristou, C.; Sideridis, G. The role of goal orientations and goal structures in explaining classroom social and affective characteristics. Learn. Individ. Differ. 2012, 22, 207-217. [CrossRef]

29. Skaalvik, E.M.; Skaalvik, S. School goal structure: Associations with students' perceptions of their teachers as emotionally supportive, academic self-concept, intrinsic motivation, effort, and help seeking behavior. Int. J. Educ. Res. 2013, 61, 5-14. [CrossRef]

30. Walker, C.O. Student perceptions of classroom achievement goals as predictors of belonging and content instrumentality. Soc. Psychol. Educ. 2012, 15, 97-107. [CrossRef]

31. Ferreira, M.; Duarte, J.; Cardoso, A.P.; Cabral, L.; Guiné, R.; Campos, S.; Alves, C. Competências emocionais e prevenção do abandono nos estudantes do ensino superior politécnico. Rev. Port. Enferm. Saúde Ment. 2018, 17-24. [CrossRef]

32. Gilar-Corbi, R.; Pozo-Rico, T.; Castejon-Costa, J.L. Improving Emotional Intelligence in Higher Education Students: Testing Program Effectiveness in Tree Countries. Educacion XX1 2019, 22, 161-187. [CrossRef]

33. Gilar-Corbi, R.; Pozo-Rico, T.; Pertegal-Felices, M.L.; Sanchez, B. Emotional intelligence training intervention among trainee teachers: A quasi-experimental study. Psicol. Reflex. Crit. 2018, 31, 33. [CrossRef]

34. Gilar-Corbi, R.; Pozo-Rico, T.; Sanchez, B.; Castejon, J.L. Can Emotional Competence Be Taught in Higher Education? A Randomized Experimental Study of an Emotional Intelligence Training Program Using a Multimethodological Approach. Front. Psychol. 2018, 9, 1039. [CrossRef]

35. Pozo-Rico, T.; Gilar, R.; Castejon, J.L. Developing Emotional Competence Training for University Students in Argentina and Spain. In Proceedings of the Inted2017: 11th International Technology, Education and Development Conference, Valencia, Spain, 6-8 March 2017; pp. 112-122.

36. Russell, J.E.; Smith, A.; Larsen, R. Elements of Success: Supporting at-risk student resilience through learning analytics. Comput. Educ. 2020, 152, 103890. [CrossRef]

37. Kotsou, I.; Mikolajczak, M.; Heeren, A.; Grégoire, J.; Leys, C. Improving emotional intelligence: A systematic review of existing work and future challenges. Emot. Rev. 2019, 11, 151-165. [CrossRef]

38. Kastberg, E.; Buchko, A.; Buchko, K. Developing Emotional Intelligence: The Role of Higher Education. J. Organ. Psychol. 2020, 20, 64-72.

39. Nelis, D.; Kotsou, I.; Quoidbach, J.; Hansenne, M.; Weytens, F.; Dupuis, P.; Mikolajczak, M. Increasing emotional competence improves psychological and physical well-being, social relationships, and employability. Emotion 2011, 11, 354. [CrossRef]

40. De Castella, K.; Byrne, D.; Covington, M. Unmotivated or motivated to fail? A cross-cultural study of achievement motivation, fear of failure, and student disengagement. J. Educ. Psychol. 2013, 105, 861. [CrossRef]

41. Tinto, V.; Cullen, J. Dropout in Higher Education: A Review and Theoretical Synthesis of Recent Research; Office of Planning, Budgeting, and Evaluation of the U.S. Office of Education: New York, NY, USA, 1973.

42. Montmarquette, C.; Mahseredjian, S.; Houle, R. The determinants of university dropouts: A bivariate probability model with sample selection. Econ. Educ. Rev. 2001, 20, 475-484. [CrossRef]

43. Gašević, D.; Dawson, S.; Siemens, G. Let's not forget: Learning analytics are about learning. TechTrends 2015, 59, 64-71. [CrossRef]

44. Macfadyen, L.P.; Dawson, S. Mining LMS data to develop an "early warning system" for educators: A proof of concept. Comput. Educ. 2010, 54, 588-599. [CrossRef]

45. Baneres, D.; Elena Rodriguez-Gonzalez, M.; Serra, M. An Early Feedback Prediction System for Learners At-Risk Within a First-Year Higher Education Course. IEEE Trans. Learn. Technol. 2019, 12, 249-263. [CrossRef]

46. Aljohani, N.R.; Daud, A.; Abbasi, R.A.; Alowibdi, J.S.; Basheri, M.; Aslam, M.A. An integrated framework for course adapted student learning analytics dashboard. Comput. Hum. Behav. 2019, 92, 679-690. [CrossRef]

47. Skaalvik, E.M. Mathematics anxiety and coping strategies among middle school students: Relations with students' achievement goal orientations and level of performance. Soc. Psychol. Educ. 2018, 21, 709-723. [CrossRef]

48. Rovayo, V.D.A. Perception on the phenomenon of student desertion in students of the Basic Education Career of the Technical University of Ambato. Rev. Pub. 2017, 4, 661-669.

49. Hsu, C.W.; Yeh, C.C. Mining the Student Dropout in Higher Education. J. Test. Eval. 2020, 48, 4563-4575. [CrossRef]

50. Govender, C.M. Hopes, Challenges and Goals-Voices of First-Year At-Risk Higher Education Students in South Africa. S. Afr. Rev. Sociol. 2020, 51, 55-69. [CrossRef] 
51. Balseca, M.A.; Parra, G.J.A. Importance of the Leveling Semester in the Entrance to Ecuadorian Universities. Rev. Conrado 2020, 16, 362-368.

52. Rotem, N.; Yair, G.; Shustak, E. Dropping out of master's degrees: Objective predictors and subjective reasons. High. Educ. Res. Dev. 2020. [CrossRef]

53. Facchini, M.; Triventi, M.; Vergolini, L. Do grants improve the outcomes of university students in a challenging context? Evidence from a matching approach. High. Educ. 2020. [CrossRef]

54. Sandoval, I.; Sánchez, T.; Velasteguí, V.; Naranjo, D. Factores Asociados Al Abandono En Estudiantes De Grupos Vulnerables. Caso Escuela Politécnica Nacional. In Proceedings of the Congresos CLABES Conferencia Latinoamericana sobre el Abandono en la Educación Superior, Ciudad de Panamá, Panamá, 14-16 November 2018.

55. Gutiérrez, R.; López, E.; Llambí, L.; May, T.; Ramírez, A.; Tocancipá-Falla, J. Higher education and indigenous nationalities: Challenges for inclusion in the ecuadorian amazonian region. Creat. Educ. 2015, 6, 847. [CrossRef]

56. Di Caudo, M. Política de cuotas en Ecuador: Me gané una beca para estudiar en la Universidad. Ponto-e-Vírgula Rev. Ciências Sociais 2015, 17, 196-218.

57. Skaalvik, E.M. Self-enhancing and self-defeating ego orientation: Relations with task and avoidance orientation, achievement, self-perceptions, and anxiety. J. Educ. Psychol. 1997, 89, 71. [CrossRef]

58. Rodríguez, S.; Cabanach, R.; Piñeiro, I.; Valle, A.; Núñez, J.; González-Pienda, J. Approach goals, avoidance goals and multiple academic goals. Psicothema 2001, 13, 546-550.

59. Suárez Riveiro, J.M.; Cabanach, R.G.; Arias, A.V. Multiple-goal pursuit and its relation to cognitive, self-regulatory, and motivational strategies. Br. J. Educ. Psychol. 2001, 71, 561-572. [CrossRef] [PubMed]

60. Valle Arias, A.; Rodríguez, S.; González Cabanach, R.; Núñez-Pérez, C.J.C.; González-Pienda, J.A.; Rosário, P. Motivational Profiles and Differences in Affective, Motivational and Achievement Variables. Univ. Psychol. 2010, 9, 109-121. [CrossRef]

61. Valle, A.; Regueiro, B.; Rodríguez, S.; Piñeiro, I.; Freire, C.; Ferradás, M.; Suárez, N. Perfiles motivacionales como combinación de expectativas de autoeficacia y metas académicas en estudiantes universitarios. Eur. J. Educ. Psychol. 2015, 8, 1-8. [CrossRef]

62. Pintrich, P.R.; De Groot, E.V. Motivational and self-regulated learning components of classroom academic performance. J. Educ. Psychol. 1990, 82, 33. [CrossRef]

63. Mayer, J.D.; Faber, M.A.; Xu, X. Seventy-five years of motivation measures (1930-2005): A descriptive analysis. Motiv. Emot. 2007, 31, 83-103. [CrossRef]

64. Schunk, D.H. Self-regulated learning: The educational legacy of Paul R. Pintrich. Educ. Psychol. 2005, 40, 85-94. [CrossRef]

65. Salovey, P.; Mayer, J.D.; Goldman, S.L.; Turvey, C.; Palfai, T.P. Emotional Attention, Clarity, and Repair: Exploring Emotional Intelligence Using the Trait Meta-Mood Scale; American Psychological Association: Washington, DC, USA, 1995.

66. Fernández-Berrocal, P.; Extremera, N.; Ramos, N. Validity and reliability of the Spanish modified version of the Trait Meta-Mood Scale. Psychol. Rep. 2004, 94, 751-755. [CrossRef] [PubMed]

67. Ilieva, G.; Yankova, T. Early Multi-criteria Detection of Students at Risk of Failure. TEM J. 2020, 9, 344-350. [CrossRef]

68. Zborovsky, G. Educational Failure of Students as a Problem of Russian Universities. In Proceedings of the INTED Proceedings, 14th International Technology, Education and Development Conference (INTED), Valencia, Spain, 2-4 March 2020; pp. 1858-1865.

69. Castillo-Sanchez, M.; Gamboa-Araya, R.; Hidalgo-Mora, R. Factors that influence student dropout and failing grades in a university mathematics course. Uniciencia 2020, 34, 219-245. [CrossRef]

70. Lin, T.C.; Yu, W.W.C.; Chen, Y.C. Determinants and probability prediction of college student retention: New evidence from the Probit model. Int. J. Educ. Econ. Dev. 2012, 3, 217. [CrossRef]

71. Flores, A.C.; Lever, J.P. El proceso de admisión como predictor del rendimiento académico en la educación superior. Univ. Psychol. 2008, 7, 199-215.

72. Castrillón, G. Factores que Inciden en la Deserción Estudiantil en el Programa Académico Administración de Empresas en la Universidad del Valle Sede Pacífico; Universidad del Valle: Buenaventura, Colombia, 2014.

73. Rojas-Torres, L. Validez predictiva de los componentes del promedio de admisión a la Universidad de Costa Rica utilizando el género y el tipo de colegio como variables de control. Rev. Actual. Investig. Educ. 2013, 13, 1-24. [CrossRef] 
74. Rodrigo, M.F.; Molina, J.G.; Ros, R.G.; González, F.P. Efectos de interacción en la predicción del abandono en los estudios de Psicología. An. Psicol. Ann. Psychol. 2012, 28, 113-119.

75. Eesley, C.E.; Lee, Y.S. Do university entrepreneurship programs promote entrepreneurship? Strateg. Manag. J. 2020. [CrossRef]

76. Brez, C.; Hampton, E.M.; Behrendt, L.; Brown, L.; Powers, J. Failure to Replicate: Testing a Growth Mindset Intervention for College Student Success. Basic Appl. Soc. Psychol. 2020, 42, 460-468. [CrossRef]

77. Valdivia-Salas, S.; Ibanez, J.; Lopez-Crespo, G.; Martin-Albo, J.; Sanchez-Martinez, R.; Castro, A. The Influence of Burnout and Psychological Inflexibility on Academic Achievement: Preliminary Evidence with Psychology Students. In Proceedings of the INTED Proceedings, 14th International Technology, Education and Development Conference, Valencia, Spain, 2-4 March 2020; pp. 2274-2280.

78. Tinajero, C.; Martinez-Lopez, Z.; Rodriguez, M.S.; Paramo, M.F. Perceived social support as a predictor of academic success in Spanish university students. An. Psicol. Spain 2020, 36, 134-142. [CrossRef]

79. Gilar, R.; Pozo-Rico, T.; Sanchez, B.; Castejon, J.L. Promote learning in emotional competence across an e-learning context for higher education. In Proceedings of the 12th International Technology, Education and Development Conference, Valencia, Spain, 5-7 March 2018; pp. 1374-1380.

80. Gilar-Corbi, R.; Pozo-Rico, T.; Castejón-Costa, J.L. Desarrollando la Inteligencia Emocional en Educación Superior: Evaluación de la efectividad de un programa en tres países. Educación XX1 2019, 22, 161-187. [CrossRef]

81. Bong, M. Age-related differences in achievement goal differentiation. J. Educ. Psychol. 2009, 101, 879. [CrossRef]

82. Midgley, C.; Kaplan, A.; Middleton, M. Performance-approach goals: Good for what, for whom, under what circumstances, and at what cost? J. Educ. Psychol. 2001, 93, 77. [CrossRef]

83. Paulick, I.; Watermann, R.; Nückles, M. Achievement goals and school achievement: The transition to different school tracks in secondary school. Contemp. Educ. Psychol. 2013, 38, 75-86. [CrossRef]

84. Bishop, R. Changing Power Relations in Education: Kaupapa Mäori Messages for "Mainstream" Education in Aotearoa/New Zealand. Counterpoints 2005, 275, 253-269. [CrossRef]

85. Gloria, A.M.; Robinson Kurpius, S.E. Influences of self-beliefs, social support, and comfort in the university environment on the academic nonpersistence decisions of American Indian undergraduates. Cult. Divers. Ethn. Minority Psychol. 2001, 7, 88. [CrossRef]

86. Klassen, R.M. Optimism and realism: A review of self-efficacy from a cross-cultural perspective. Int. J. Psychol. 2004, 39, 205-230. [CrossRef]

87. Van Dinther, M.; Dochy, F.; Segers, M. Factors affecting students' self-efficacy in higher education. Educ. Res. Rev. 2011, 6, 95-108. [CrossRef]

88. Bandura, A.; Schunk, D.H. Cultivating competence, self-efficacy, and intrinsic interest through proximal self-motivation. J. Personal. Soc. Psychol. 1981, 41, 586. [CrossRef]

89. Barouch-Gilbert, A. Academic probation: Student experiences and academic probation: Student experiences and self-efficacy enhancement. J. Ethnogr. Qual. Res. 2016, 10, 153-164.

90. Becker, S.P.; Gable, R.K. The relationship of self-efficacy and GPA, attendance, and college student retention. In Proceedings of the NERA Conference Proceedings, 40th Annual Conference of the Northeastern Educational Research Association, Rocky Hill, CT, USA, 21-23 October 2009.

91. Frawley, J.; Ober, R.; Olcay, M.; Smith, J.A. Indigenous Achievement in Higher Education and the Role of self-Efficacy: Rippling Stories of Success; National Centre for Student Equity in Higher Education (NCSEHE): Perth, Australia, 2017.

92. Sandoval-Palis, I.; Naranjo, D.; Vidal, J.; Gilar-Corbi, R. Early Dropout Prediction Model: A Case Study of University Leveling Course Students. Sustainability 2020, 12, 9314. [CrossRef]

Publisher's Note: MDPI stays neutral with regard to jurisdictional claims in published maps and institutional affiliations. 